\title{
Regressing Friend Leukemia Virus
}

National Cancer Institute

\section{Source}

National Cancer Institute. Regressing Friend Leukemia Virus. NCI Thesaurus. Code C29889.

Animals inoculated with the regressing strain of Friend virus exhibited an initial pathologic response identical to that induced by conventional strains of Friend virus. Unlike the fatal leukemia produced by conventional Friend virus, the pathology of the disease induced by the regressing strain of Friend virus regresses in 50\% of leukemic mice. 